\title{
Airway management in children with COVID-19
}

\author{
Karen KY Leung, SW Ku, Ronald CM Fung, WF Hui, CC Au, WL Cheung, WH Szeto, Jeff CP Wong, \\ KF Kwan, KL Hon *
}

\section{A B S T R A C T}

The novel coronavirus disease (COVID-19) may result in acute respiratory distress syndrome and respiratory failure, necessitating mechanical respiratory support. Healthcare professionals are exposed to a particularly high risk of contracting the virus while providing resuscitation and respiratory support, which may in turn result in grave consequences and even death. Although COVID-19 has been shown to cause milder disease in children, paediatricians and intensivists who provide care for children must be prepared to provide optimal respiratory support without putting themselves or other medical, nursing, and paramedical staff at undue risk. We propose an airway management approach that is especially relevant in the current COVID-19 pandemic and provides instructions for:

(1) Elective intubation for respiratory failure; and

(2) Emergency intubation during cardiopulmonary resuscitation. To minimise risk, intubation methods must be kept as straightforward as possible and should include the provision of appropriate personal protection and equipment to healthcare workers. We identify two key considerations: that bag-mask ventilation should be avoided if possible and that

bacterial and viral filters should be placed in the respiratory circuit. Our novel approach provides a framework for airway management that could benefit paediatric critical care practitioners who provide care for any children with a novel viral illness, with a focus on infection prevention during high-risk airway management procedures.

\section{${ }^{1}$ KKY Leung, MB, BS, MRCPCH \\ ${ }^{1} \mathrm{SW}$ Ku, MB, BS, MRCP \\ ${ }^{1}$ RCM Fung, MB, ChB, MRCPCH \\ ${ }^{1}$ WF Hui, MB, ChB, MRCPCH \\ ${ }^{1} \mathrm{CC} \mathrm{Au}, \mathrm{MB}, \mathrm{BS}, \mathrm{MRCPCH}$ \\ ${ }^{1}$ WL Cheung, MB, BS, MRCPCH \\ ${ }^{1}$ WH Szeto, BNurs, MNurs \\ 1 JCP Wong, MB, BS, MRCPCH \\ ${ }^{2}$ KF Kwan, MB, BS, MRCP (Irel) \\ ${ }^{1} \mathrm{KL}$ Hon *, MB, BS, MD}

Hong Kong Med J 2022;28:315-20

https://doi.org/10.12809/hkmj208709

Paediatric Intensive Care Unit, Department of Paediatrics and Adolescent Medicine, The Hong Kong Children's Hospital, Hong Kong

2 Department of Paediatrics and Adolescent Medicine, The Hong Kong Children's Hospital, Hong Kong

\section{Introduction}

In late 2019, a novel coronavirus named severe acute respiratory syndrome coronavirus 2 (SARS-CoV-2) spread to become a global pandemic, which is now termed coronavirus disease 2019 (COVID-19). ${ }^{1-5}$ At the time of writing, more than 12 million people worldwide have been infected, with a crude mortality ratio of approximately $5 \%{ }^{6}$

In both of the erstwhile SARS and MERS epidemics, there were reported cases of transmission to healthcare workers. ${ }^{7,8}$ Many physicians and allied health staff have contracted SARS-CoV, some of whom have died of the infection. Endotracheal intubation is considered as one of the highest risk procedures in the context of disease transmission., ${ }^{9,10}$ During the SARS outbreak, $21 \%$ of cases worldwide were among healthcare workers. ${ }^{7}$ Caputo et al $^{11}$ estimated that $9 \%$ of the interviewed healthcare workers who performed an intubation ended up contracting SARS. Intubation is a high-risk aerosolgenerating procedure, and the odds ratio to contract SARS for healthcare workers performing tracheal intubation is 6.6 compared with those who did not perform this procedure. ${ }^{12}$

In the setting of COVID-19, SARS-CoV-2 is a highly contagious, novel virus with many still-unknown characteristics. Recent literature on healthcare-related transmission of COVID19 revealed that up to $20 \%$ of infections among healthcare workers were in those caring for patients with COVID-19, and that hospital-related transmission was suspected in $41 \%$ of patients. ${ }^{13,14}$ Amidst the COVID-19 pandemic, it is essential for paediatricians and intensivists to be equipped with clear intubation guidelines. ${ }^{15,16}$

\section{Tracheal intubation of paediatric patients with COVID-19}

In January 2020, we promptly developed a novel approach and protocol in preparation for the management of critically ill paediatric patients with COVID-19. Although several adult intensive care unit guidelines exist in the public domain, there are currently no standard or unified paediatric-specific guidelines in the literature. ${ }^{17-19}$ Adult intubation guidelines cannot be applied directly to paediatric 


\section{9 冠狀病毒病兒童患者的氣道管理}

\section{梁嘉恩、古樹榮、馮卓文、許桓峰、區卓仲、張穎琳、 司徒詠嫻、黃展鵬、關國勳、韓錦倫}

新型2019冠狀病毒病可能導致急性呼吸窘迫綜合徵和呼吸衰竭, 需 要機械呼吸機幫助。在提供復更生和呼吸幫助的同時, 醫護人員面臨感 染病毒的特高風險, 這反過來可導致嚴重後果甚至死亡。儘管已證明 2019 冠狀病毒病會引起兒童輕度疾病, 但為兒童提供護理的兒科醫生 和深切治療部醫生須作好準備, 為患者提供最佳的呼吸幫助而不會使 自己或其他醫療、護理和輔助醫療人員承受過度風險。我們提出與當 前2019冠狀病毒病大流行特別相關的氣道管理方法, 並提供以下指 引, 包括：（1）呼吸衰竭時進行選擇性插管和（2）心肺復蘇時緊急 插管。為了將風險減至最低, 插管方法必須盡可能簡單直接, 並且應 包括向醫護人員提供適當的個人防護裝備。我們確定兩個主要考慮因 素, 包括：（1）盡量避免使用氣囊面罩通氣, 以及 (2) 呼吸管路中 應放置細菌和病毒過濾器。我們的新方法為氣道管理提供治療框架, 該框架可以使為所有新型病毒病兒童患者提供護理的兒童深切治療部 人員受益, 重點在於高危氣道管理程序中的感染預防 practice, as children can present at wide age and weight ranges. In addition, there is a difference in physiology: children have higher rates of oxygen consumption and smaller functional residual capacity. Therefore, we tested different circuit configurations for endotracheal intubation and propose variations for the following hypothetical scenarios: (1) elective intubation for respiratory failure; and (2) emergency intubation during cardiopulmonary resuscitation.

\section{Preparation for intubation: venue, personnel, and equipment}

Any paediatric patient who is suspected or confirmed to be infected with SARS-CoV-2 should be cared for in a single airborne infection isolation room with negative pressure relative to the atmosphere, and the outgoing air should be passed through a high-efficiency particulate air (HEPA) filter. ${ }^{20}$ All healthcare workers should wear personal protective equipment appropriate for airborne pathogens when caring for the patient, including a fit-tested N95 respirator, goggles, a face shield, a fluid-resistant non-sterile gown, and a pair of clean non-sterile gloves. Staff should receive training and practice donning and doffing of personal protective equipment according to standard protocols. Although SARS-CoV-2 is supposedly transmitted by droplets instead of being airborne, healthcare workers are advised to adopt airborne precautions in face of this rapidly transmitting and novel pathogen with uncertain viral characteristics. ${ }^{21}$ Ideally, the most experienced healthcare professional should perform the intubation with two other assistants. In the event that cricoid pressure is not given, it may be possible to have one less assistant to reduce potential exposure.

Age- and weight-appropriate airway equipment should ideally be prepared ahead of time and made readily available by the bedside (Fig 1 ). Single-use or dedicated equipment must be used. A cuffed endotracheal tube (ETT) is preferable. As bagmask ventilation prior to intubation can generate aerosols, the practice should be avoided as far as practicable. ${ }^{22}$ We suggest setting up a closed-circuit bagging system that can be connected to a bedside scavenger to reduce the risk of viral transmission by employing unidirectional gas flow directed away from the patient's side (Fig 2). A similar scavenger system has been used in ventilator and neonatal resuscitation circuits for suspected cases of SARS and COVID-19. ${ }^{23,24}$ This circuit can also be configured with a modified Ayre's T-piece and either a 0.5 -L bag for children weighing $\leq 20 \mathrm{~kg}$ or a 2 - $\mathrm{L}$ bag for children weighing $>20 \mathrm{~kg}$. Furthermore, a bacterial and viral filter (preferably a HEPA filter) should be added to the system to reduce the risk of spreading the airborne pathogens to the breathing system and the ambient air. ${ }^{25}$ However, the choices for HEPA filters for paediatric patients are limited, as most HEPA filters on the market are designed for adult patients (ie, they require a tidal volume of at least 200-300 mL). A filter should always be placed between the face mask and the connecting tube of the T-piece circuit to filter all expired gas, and we further recommend placing an additional filter between the reservoir breathing bag and the suction tube to filter all scavenging gas, which would increase the filtration efficacy and reduce the risk of viral transmission to the ambient air. The manufacturers' published filter specifications could be different from the actual filtration performance, as filtration efficiency can depend on temperature and humidity. ${ }^{26,27}$ Theoretically, based on the size of SARS-CoV-2 (0.06-0.2 $\mu \mathrm{m})$, it can be removed by HEPA filters. However, manufacturers and suppliers might not have validated these filters for removal of the SARS-CoV-2 virus; therefore, we suggest that extra precautions are necessary. ${ }^{27-29}$ Oral suction during intubation is unavoidably an open suction procedure, and it is also regarded as an aerosolgenerating procedure. Thus, it should be performed only after the administration of adequate muscle relaxant and only when there is genuine need (eg, when secretions obscure the larynx).

If available, video laryngoscopy should be used to increase the chance of successful intubation on the first pass, with the screen ideally located at the operator's eye level. Another advantage of video laryngoscopy is that a longer distance can be maintained between the intubation field and the operator, reducing the risk of transmission. 

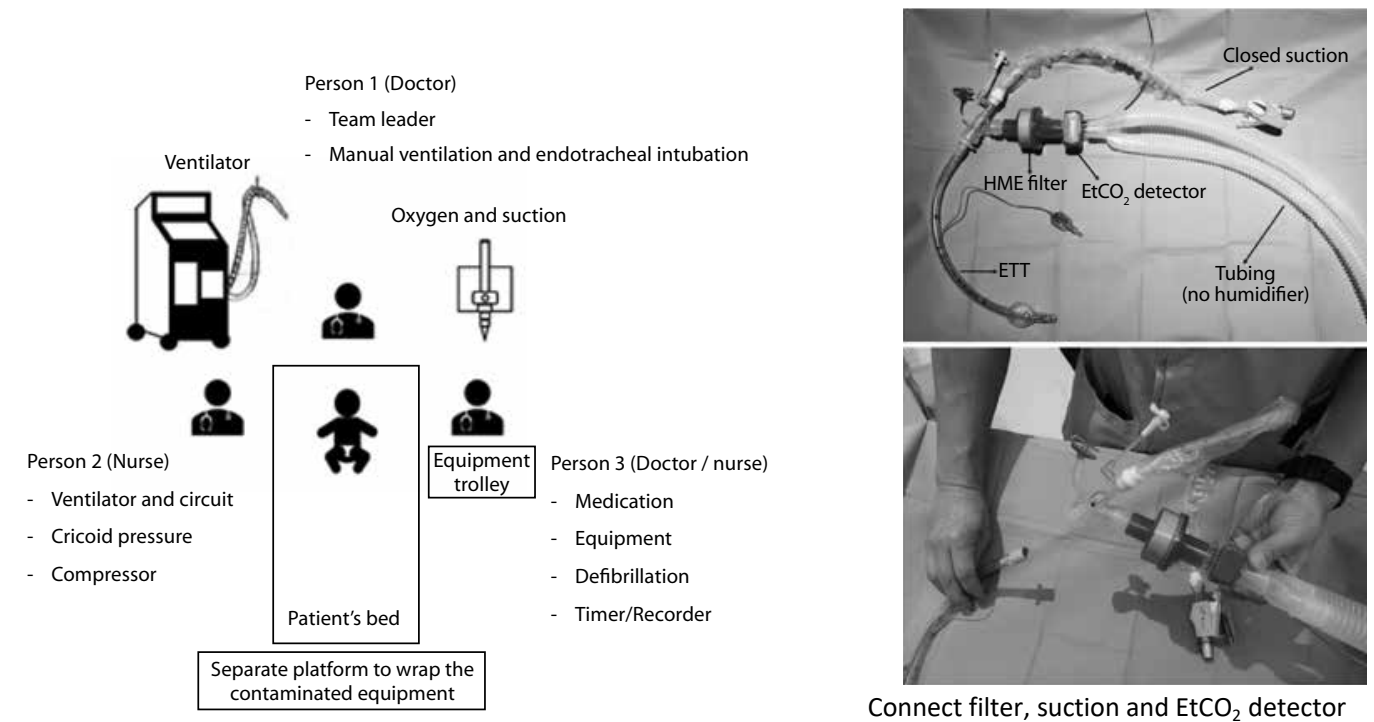

Connect filter, suction and $\mathrm{EtCO}_{2}$ detector

(disposable) in one-piece to the ETT after successful intubation

\section{Procedure of endotracheal intubation}

- Person 1:

- Apply modified T-piece with face mask with 2 hands and ensure tight seal

- Start oxygen flow at about 3 times the estimated minute volume or directly $15 \mathrm{~L} / \mathrm{min}$ for older child

- Monitor breathing by movement of the reservoir bag. Person 3 may provide PEEP or manual bagging ONLY IF needed to reduce risk of aerosol generation and spillage of secretions

- Pre-oxygenation for around 3-5 minutes before rapid sequence induction (Person 3)

- Person 2: Apply cricoid pressure

- After adequate muscle paralysis, person 1 removes face mask with T-piece from patient and perform intubation

- $\quad$ Person 3: Pass the laryngoscope, ETT with stylet or bougie to person 1

- After ETT insertion, person 3 inflates ETT cuff as instructed by person 1

- Person 2: Release cricoid pressure and connect filter, suction and $\mathrm{EtCO}_{2}$ monitor in one piece to the ETT after successful intubation. Observe $\mathrm{EtCO}_{2}$ tracing

- $\quad$ Tape and secure ETT position by person 1 and 3

\begin{tabular}{|c|c|c|c|}
\hline \multicolumn{2}{|c|}{ Rescue plan } & \multicolumn{2}{|c|}{ Equipment list } \\
\hline Failed intubation & Severe desaturation & - Medications for & - Direct laryngoscope: 2 \\
\hline 5 & S & resuscitation & - Intubation stylet \\
\hline \multirow{2}{*}{\multicolumn{2}{|c|}{$\begin{array}{ll}\text { - Insert a LMA } \\
\text { - Connect modified T-piece to LMA } \\
\text { - Maintain adequate oxygen flow to inflate the } \\
\text { reservoir bag and manually ventilate using T-piece }\end{array}$}} & - Yankauer sucker: $\geq 2$ & - Gum elastic bougie \\
\hline & & - Oropharyngeal airway: 2 & - monitor \\
\hline & & race mask: 2 alitrerent & - positioning \\
\hline \multicolumn{2}{|c|}{ After inserting the LMA } & - Cutted tII: 0.5 size up & - Intravenous fluia for \\
\hline & Z & - LMA: 1 size up and & - Ambubag with oxygen \\
\hline Call for help & Continue manual ventilation & - Syringe: $3 \mathrm{~mL} / 5 \mathrm{~mL} /$ & - Nasogastric tube \\
\hline $\begin{array}{l}\text { Continue manual } \\
\text { ventilation using }\end{array}$ & until achieving desired $\mathrm{SpO} 2$ & $10 \mathrm{~mL} / 20 \mathrm{~mL} \geq 2$ each & - Cricothyroid puncture \\
\hline until help arrives & - No crico & - Video laryngoscope with & - Equipment for vascular \\
\hline & & & $\begin{array}{l} \pm \text { intraosseous access } \\
\text { - Mobile / walkie-talkie } \\
\text { - Pens / papers }\end{array}$ \\
\hline
\end{tabular}

FIG I. Guideline for intubating a child with coronavirus disease 2019

Abbreviations: $\mathrm{HME}=$ heat and moisture exchanger; $\mathrm{EtCO}_{2}=$ end-tidal $\mathrm{CO}_{2} ; \mathrm{LMA}=$ laryngeal mask airway; $\mathrm{PEEP}=$ positive end expiratory pressure 


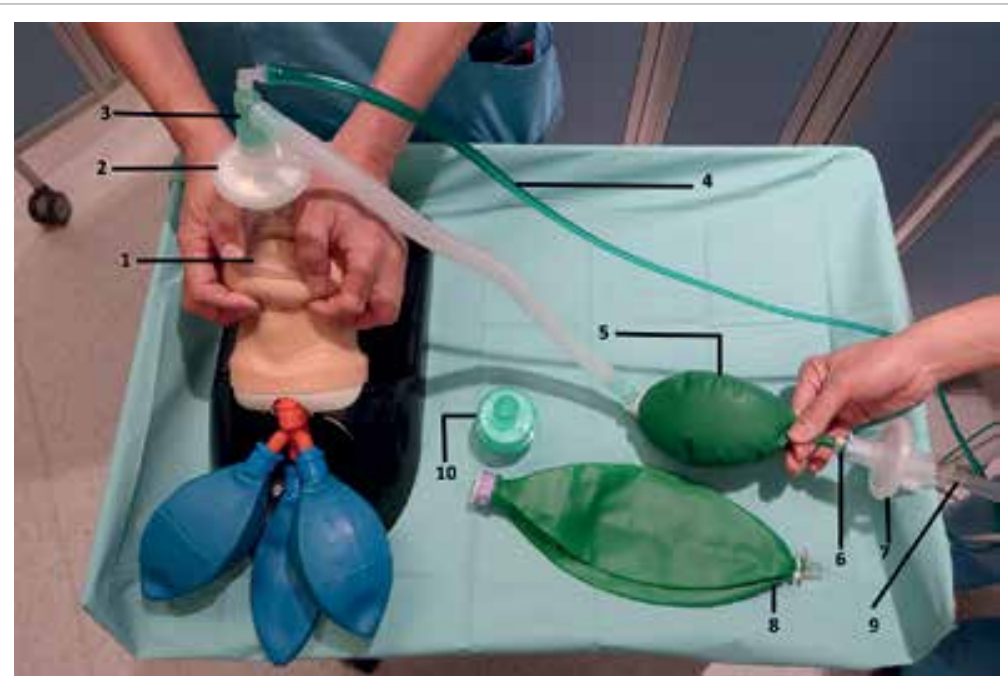

FIG 2. Setup of the circuit with a scavenger system

Positive end-expiratory pressure and ventilation can be applied using the reservoir bag. I: Face mask; 2 and 7: Bacterial and viral filter, high-efficiency particulate air filter, or heat and moisture exchanger filter; 3: Modified Ayre's T-piece; 4: Oxygen supply; 5: Reservoir bag ( $0.5 \mathrm{~L}$ for children weighing $\leq 20 \mathrm{~kg}$ ); 6 : Endotracheal tube connector; 8: Reservoir bag ( $2 \mathrm{~L}$ for children weighing > $20 \mathrm{~kg}$ ); 9: Connection to suction and scavenger system (within $80 \mathrm{~mm} \mathrm{Hg}$ ); 10 : Heat and moisture exchanger filter
A ventilator circuit with heat and moisture exchanger filter (HMEF), closed suction system, and mainstream end-tidal $\mathrm{CO}_{2}$ monitor (preferably disposable airway adaptor) should be prepared and connected to the ETT in one piece, which minimises any further disconnection of the circuit after successful intubation (Fig 1). We recommend the use of HMEF for paediatric patients as water bath humidifiers may increase the risk of infection dissemination. Although there might be increased risk of sputum retention with the use of HMEF, especially in small children, close monitoring and regular close suction can reduce this risk. Previous studies showed that water bath humidifiers can produce aerosols containing bacteria, and they could also potentially carry SARS-CoV-2.30,31

\section{Scenario 1: Elective intubation for respiratory failure}

Patients should be pre-oxygenated by spontaneous breathing using the modified Ayre's T-piece system with a tight-fitting face mask using the two-hand technique of bag-mask ventilation. Oxygen flow should be started at about 3 times the estimated minute volume, and the flow of oxygen and suction should be adjusted to keep the reservoir bag partially inflated. The operator's attention should be directed to the reservoir bag's inflation, as this provides an indication of whether a tight seal, adequate positive end expiratory pressure (PEEP), and an intact circuit are maintained. Manual bagging should be avoided as much as possible. Rapid sequence induction should be used to optimise the chance of success on the first attempt and to minimise any coughing or gag reflex during intubation. ${ }^{22}$ After 5 minutes of pre-oxygenation, apart from other sedatives for rapid sequence induction, an adequate muscle relaxant (eg, rocuronium $1.2 \mathrm{mg} / \mathrm{kg}$ ) can be administered to the patient. ${ }^{32}$ Cricoid pressure can then be applied. After adequate muscle paralysis, the patient can be intubated with a cuffed ETT. Once the ETT has been passed though the cords to the proper depth, the cuff should be immediately inflated. After successful intubation and cuff inflation, the clinician must ensure that there is no leakage around the cuff. Finally, the ETT can be connected to the prepared ventilator, and ventilation should be started immediately to avoid bagging as far as possible.

If the intubation attempt is not successful, or if severe desaturation persists despite pre-oxygenation without bagging, a laryngeal mask airway can be inserted. Manual ventilation should be continued using the laryngeal mask airway and the modified T-piece system with adequate oxygen flow until help arrives. For subsequent intubation attempts, clinicians can consider using the ETT stylet or Bougie techniques.

\section{Scenario 2: Emergency intubation during cardiopulmonary resuscitation}

Generally, the patient should be intubated as soon as possible because bagging with a face mask risks generating aerosols. ${ }^{10}$ Other than using the twohand technique for tight mask fitting, leaking can also be minimised by using laryngeal mask airway during cardiopulmonary resuscitation, particularly if a difficult airway is anticipated or if an experienced operator is not available.

After successful intubation, clinicians should inflate the cuff and connect the ETT to the ventilator immediately while adjusting the ventilator settings in accordance with the patient's age and weight. It is also important to make sure that endtidal $\mathrm{CO}_{2}$ monitoring is available, as it is crucial to ensure correct placement of ETT and the return of spontaneous circulation.

\section{Discussion}

All of the equipment mentioned in this proposed intubation approach should be commercially available in most hospitals worldwide that provide paediatric services. Our proposed system provides multiple key functions, including respiratory pattern monitoring, spontaneous respiration oxygenation, apnoeic oxygenation, manual ventilation, and scavenging.

Our approach has several advantages. It is 
a closed breathing system, provided that the face mask has a tight seal and clinicians use the twohand technique, which can minimise the risk of contaminated secretions leaking out. It allows contaminated gases to flow in the direction of the scavenging system, and manual ventilation is possible by squeezing the reservoir bag if necessary. Positive end expiratory pressure can be maintained by partially occluding the tail of the reservoir bag. This is especially important in the paediatric population, as children have a low functional residual capacity, and the addition of PEEP during pre-oxygenation can potentially minimise or prevent functional residual capacity reduction, airway closure, and subsequent atelectasis. The patient's breathing pattern can be monitored by the movement of the reservoir bag. Finally, a manometer can be connected to the circuit if the operator prefers to monitor pressure in the circuit. $^{33}$

Users should be aware of some potential limitations of our approach. First, the use of an Ayre's T-piece with Jackson-Rees modification requires training. Second, adequate pre-oxygenation is required, as there is no oxygen supply during the period between removing the face mask from the patient and successful endotracheal intubation. Third, $\mathrm{CO}_{2}$ rebreathing may occur if the patient's minute volume is high. This can be mitigated by using a T-piece with fresh gas flow configured to 2 to 3 times the minute volume. For example, if the fresh oxygen flow is $15 \mathrm{~L} / \mathrm{min}, \mathrm{CO}_{2}$ rebreathing may occur if the patient's minute volume is more than 5 to $7.5 \mathrm{~L} / \mathrm{min}$; Fourth, the system cannot be used in areas with no oxygen supply. Finally, the whole system might be under negative pressure during the entire expiratory phase, which may lead to alveolar collapse. The application of a low level of PEEP to the anaesthetic bag would prevent this from occurring. Further, clinical and radiological evaluations are indicated to ensure that there is no significant atelectasis.

With adequate training and practice, our proposed approach to intubation should be safe and effective. We would welcome further research in a laboratory setting to test the system's integrity and quantitatively measure the reductions in aerosols that it generates.

\section{Conclusion}

Amidst the current pandemic, in which much remains unknown about the coronavirus and COVID-19 disease, healthcare workers should take the highest levels of precautions and protection when providing care to patients with suspected SARS-CoV-2 infection and respiratory failure. By sharing the approach we have developed for endotracheal intubation, we aim to raise awareness of the precautions that need to be taken during intubation to reduce the risk of healthcare-related transmission, not only in the current COVID-19 pandemic, but also in future outbreaks of airborne pathogens. ${ }^{34}$ A review of all published paediatric airway and intubation protocols is now underway to evaluate this important management facet in paediatrics. Paediatricians should be as well prepared as physicians who care for adults.

\section{Author contributions}

All authors contributed to the concept or design of the study, acquisition of the data, analysis or interpretation of the data, drafting of the manuscript, and critical revision of the manuscript for important intellectual content. All authors had full access to the data, contributed to the study, approved the final version for publication, and take responsibility for its accuracy and integrity.

\section{Conflicts of interest}

As an editor of the journal, KL Hon was not involved in the peer review process. Other authors have no conflicts of interest to disclose.

\section{Funding/support}

This research received no specific grant from any funding agency in the public, commercial, or not-for-profit sectors.

\section{References}

1. Zhu N, Zhang D, Wang W, et al. A novel coronavirus from patients with pneumonia in China, 2019. N Engl J Med 2020;382:727-33.

2. Huang C, Wang Y, Li X, et al. Clinical features of patients infected with 2019 novel coronavirus in Wuhan, China. Lancet 2020;395:497-506.

3. Hon KL, Leung KK. Severe acute respiratory symptoms and suspected SARS again 2020. Hong Kong Med J 2020;26:78-9.

4. World Health Organization. Naming the coronavirus disease (COVID-19) and the virus that causes it. Available from: https://www.who.int/emergencies/diseases/novelcoronavirus-2019/technical-guidance/naming-thecoronavirus-disease-(covid-2019)-and-the-virus-thatcauses-it. Accessed 24 Feb 2020.

5. Hon KL, Leung KK, Leung AK, et al. Overview: the history and pediatric perspectives of severe acute respiratory syndromes: novel or just like SARS. Pediatr Pulmonol 2020;55:1584-91.

6. Coronavirus Resource Center, Johns Hopkins University. COVID-19 dashboard by the Center for Systems Science and Engineering at Johns Hopkins University. 2020. Available from: https://coronavirus.jhu.edu/map.html. Accessed 10 Jul 2020.

7. World Health Organization. Summary of probable SARS cases with onset of illness from 1 November 2002 to 31 July 2003. Available from: https://www.who.int/csr/sars/ country/table2004_04_21/en/. Accessed 4 Jan 2020.

8. Al-Tawfiq JA, Auwaerter PG. Healthcare-associated infections: the hallmark of Middle East respiratory syndrome coronavirus with review of the literature. J Hosp Infect 2019;101:20-9. 
9. Fowler RA, Guest CB, Lapinsky SE, et al. Transmission of severe acute respiratory syndrome during intubation and mechanical ventilation. Am J Respir Crit Care Med 2004;169:1198-202.

10. Chan MT, Chow BK, Lo T, et al. Exhaled air dispersion during bag-mask ventilation and sputum suctioningimplications for infection control. Sci Rep 2018;8:198.

11. Caputo KM, Byrick R, Chapman MG, Orser BA, Orser BJ. Intubation of SARS patients: infection and perspectives of healthcare workers. Can J Anesth 2006;53:122-9.

12. Tran K, Cimon K, Severn M, Pessoa-Silva CL, Conly J. Aerosol generating procedures and risk of transmission of acute respiratory infections to healthcare workers: a systematic review. PLoS One 2012;7:e35797.

13. Remuzzi A, Remuzzi G. COVID-19 and Italy: what next? Lancet 2020;395:1225-8.

14. Wang D, Hu B, Hu C, et al. Clinical characteristics of 138 hospitalized patients with 2019 novel coronavirus-infected pneumonia in Wuhan, China. JAMA 2020;323:1061-9.

15. Li Q, Guan X, Wu P, et al. Early transmission dynamics in Wuhan, China, of novel coronavirus-infected pneumonia. N Engl J Med 2020;382:119-207.

16. Wu JT, Leung K, Leung GM. Nowcasting and forecasting the potential domestic and international spread of the 2019-nCoV outbreak originating in Wuhan, China: a modelling study. Lancet 2020;395:689-97.

17. Cheung JC, Ho LT, Cheng JV, Cham EY, Lam KN. Staff safety during emergency airway management for COVID19 in Hong Kong. Lancet Respir Med 2020;8:e19.

18. Yao W, Wang T, Jiang B, et al. Emergency tracheal intubation in 202 patients with COVID-19 in Wuhan, China: lessons learnt and international expert recommendations. $\mathrm{Br} \mathrm{J}$ Anaesth 2020;125:e28-37.

19. Brewster DJ, Chrimes N, Do TB, et al. Consensus statement: Safe Airway Society principles of airway management and tracheal intubation specific to the COVID-19 adult patient group. Med J Aust 2020;212:472-81.

20. American Society of Anesthesiologists. COVID-19 Information for health care professionals. 2020. Available from: https://www.asahq.org/about-asa/governance-andcommittees/asa-committees/committee-on-occupationalhealth/coronavirus. Accessed 6 Feb 2020.

21. World Health Organization. Infection prevention and control during health care when novel coronavirus ( $\mathrm{nCoV}$ ) infection is suspected. Interim guidance. Available from: https://www.who.int/publications/i/item/10665-331495. Accessed 9 Feb 2020.

22. Wax RS, Christian MD. Practical recommendations for critical care and anesthesiology teams caring for novel coronavirus (2019-nCoV) patients. Can J Anaesth 2020;67:568-76.

23. Ng PC, So KW, Leung TF, et al. Infection control for SARS in a tertiary neonatal centre. Arch Dis Child Fetal Neonatal Ed 2003;88:F405-9.

24. Trevisanuto D, Moschino L, Doglioni N, Roehr CC, Gervasi MT, Baraldi E. Neonatal resuscitation where the mother has a suspected or confirmed novel coronavirus (SARS-CoV-2) infection: suggestion for a pragmatic action plan. Neonatology 2020;117:133-40.

25. Heuer JF, Crozier TA, Howard G, Quintel M. Can breathing circuit filters help prevent the spread of influenza A (H1N1) virus from intubated patients? GMS Hyg Infect Control 2013;8:Doc09.

26. Dellamonica J, Boisseau N, Goubaux B, Raucoules-Aimé M. Comparison of manufacturers' specifications for 44 types of heat and moisture exchanging filters. Br J Anaesth 2004;93:532-9.

27. Fisher \& Paykel Healthcare. Viral \& bacterial filtration efficiency of Fisher \& Paykel healthcare filters and F\&P Evaqua $^{\text {TM }} 2$ circuits. 2020. Available from: https://www. fphcare.com/us/covid-19/filters-evaqua-circuits-covid19/\#tested-covid. Accessed 13 Jul 2020.

28. Hamilton Medical. Efficiency of HEPA filters. 2020. Available from: https://www.hamilton-medical.com/ fr_CH/E-Learning-and-Education/Knowledge-Base/ Knowledge-Base-Detail 2020-03-18 Efficiency-ofHEPA-filters d5358f88-753e-4644-91c6-5c7b862e941f . html. Accessed 13 Jul 2020.

29. Smiths Medical. HEPA filter information. 23 Mar 2020. Available from: https://www.smiths-medical.com/ company-information/news-and-events/news/2020/ march/23/hepa-filter-letter. Accessed 13 Jul 2020.

30. Gilmour IJ, Boyle MJ, Streifel A, McComb RC. The effects of circuit and humidifier type on contamination potential during mechanical ventilation: a laboratory study. Am J Infect Control 1995;23:65-72.

31. Al Ashry HS, Modrykamien AM. Humidification during mechanical ventilation in the adult patient. Biomed Res Int 2014;2014:715434.

32. World Health Organization. Clinical management of severe acute respiratory infection when novel coronavirus ( $\mathrm{nCoV}$ ) infection is suspected: interim guidance, 28 January 2020. Available from: https://apps.who.int/iris/ handle/10665/330893. Accessed 11 Feb 2020.

33. Trachsel D, Svendsen J, Erb TO, von Ungern-Sternberg BS. Effects of anaesthesia on paediatric lung function. Br J Anaesth 2016;117:151-63.

34. Hon KL. Just like SARS. Pediatr Pulmonol 2009;44:1048-9. 